www.jmscr.igmpublication.org Impact Factor 5.244

Index Copernicus Value: 83.27 ISSN (e)-2347-176x ISSN (p) 2455-0450 crossref DOI: _https://dx.doi.org/10.18535/jmscr/v4i12.36

\title{
Correlation of Fetal Hemoglobin (HbF) with Clinical Findings and red cell indices in Thalassemia: 'Harbinger of HbF Inducer Therapies'
}

\author{
Authors \\ Sharmila Gupta ${ }^{1}$, Ashok Kumar Kapoor ${ }^{2}$, Vidya Bhushan ${ }^{3}$, Ashutosh Kumar ${ }^{4}$, Upama $^{5}$ \\ Department of Pathology ${ }^{1,2}$, Nepalgunj Medical College, Nepalgunj, Nepal and \\ ${ }^{3}$ Department of Community Medicine and Pathology ${ }^{4}$, \\ King George Medical University, Lucknow, Uttar Pradesh, India-226003 \\ ${ }^{5}$ RML Pathology Pvt Limited, Niralanagar, Lucknow
}

Corresponding Author

Dr Ashok Kumar Kapoor

D87 Mahanagar Extension, Vigyan Puri, Lucknow, Uttar Pradesh, India-226006

Email: drashokkapoor2016@gmail.com

\section{ABSTRACT}

Aim of this study was to correlate the fetal hemoglobin $(\mathrm{HbF})$ values with red cell indices in patients with thalassemia. Present study was done on 9 patients with thalassemia. All the 9 patients belonged to Tharu Chaudhary community and hailed from mid-western region of Nepal. Thirteen subjects with abnormal hemoglobin structure acted as disease-controls. Eight other subjects with normal hemoglobin structure were also taken as disease-controls. All the subjects $(n=30)$ included in this study had microcytic hypochromic anemia. Venous blood was collected from all the patients. Blood cells were washed and lysed. Later, Hb electrophoresis was done. Hb electrophoresis revealed presence of HbF in blood of 8 of 9 thalassemic patients. $\mathrm{HbF}$ values ranged from $2 \%$ to $96 \%$ in patients. HbF was inversely correlated with $M C H C$ and $M C V . H_{2} A_{2}$ was also correlated with Hct and RBC. Findings of this study suggested that rise in $\mathrm{HbF}$ in thalassemic patients may improve hypochromia and thus may favor survival of red cells.

\section{INTRODUCTION}

Thalassemic patients have reduced MCV. MCV of $72 \mathrm{fl}$ is maximally sensitive and specific for presumptive diagnosis of thalassemia syndromes. Thalassemias tend to produce a uniform red cell diameter without a concomitant increase in $\mathrm{RDW}^{1}$. Studies correlating $\mathrm{HbF}$ with red cell indices are few. Therefore, the present study was planned to correlate the level of $\mathrm{HbF}$ with red cell indices in thalassemic patients.

\section{MATERIALS AND METHODS}

It was planned to investigate the etiopathogenesis of 30 subjects with microcytic hypochromic anemia. Accordingly, the subjects were investigated. The subjects had severe or moderate anemia. Subjects mainly belonged to Banke ( $\mathrm{n}=$ 16), Bardiya $(n=8)$ and Dang $(n=4)$ districts of Nepal. In addition, 1 patient each came from Surkhet and Dhangadi districts. The subjects were clinically examined and findings were recorded on a specially designed proforma. About $2.5 \mathrm{ml}$ of venous blood was collected in EDTA 
and blood smears were prepared. Later, detailed hemogram was obtained using automatic cell counter (Nihon Kohden Celltac, E Germany). Total $\mathrm{Hb}$ was estimated by cyanmethemoglobin method $^{2}$. Blood smears were stained by Leishman method. Reticulocyte index was calculated ${ }^{3}$. Slide-based sickling test was done using Sodium metasulphite.

Preparation of hemolysate: EDTA blood was washed $\times 3$ with normal saline. The packed blood cells were lysed with distilled $\mathrm{H}_{2} \mathrm{O}$ and centrifuged. Supernatant was collected as hemolysate and stored at $+4^{\circ} \mathrm{C}$.

Fetal hemoglobin estimation: $\mathrm{HbF}$ was estimated using 2 different methods, e.g. acid elution cytochemical method ${ }^{2}$ and agarose gel electrophoresis at alkaline $\mathrm{pH}$ 8.6.

(a) Acid elution cytochemical method: Fresh blood smears were air-dried and fixed in $80 \%$ ethanol. Smears were placed in elution solution containing hematoxylin and ferric chloride. Smears were counter-stained with eosin. Later, fetal cells were counted ${ }^{2}$.

(b) Agarose gel electrophoresis at alkaline pH

8.6: Five $\mu$ l of hemolysate was charged into well plates using a unit applicator, the sample was applied into the alkaline hemoglobin agarose gel along with suitable controls and immediately placed in electrophoresis chamber. The sample was electrophoresed at $100 \mathrm{~V}$ for 45 minutes. The agarose gel was transferred toa developer unit where it was fixed and stained. The equipment was supplied by Biotec-Fischer GMBH Maestro101, Germany. Good separation of $\mathrm{HbA}$, $\mathrm{HbF}, \mathrm{HbS}$ and $\mathrm{HbC}$ was obtained by this method. On the basis ofabove investigations, 9 subjects were found to be suffering from $\beta$ thalassemia and they were labeled as Patients. One of the subjects among thepatient group showed an additional fast moving band. Ten of 30 subjects gave positive sickling reaction; these subjects also showed $\mathrm{HbS}$ band by hemoglobin electrophoresis. These subjects were diagnosed as having sickle hemoglobin. In addition, 3 other subjects had $\mathrm{HbD}$ disease. These 13 subjects were collectively included as Disease-controls with abnormal structure. Eight other subjects had normal $\mathrm{Hb}$ structure. These subjects were labeled as Diseasecontrols with normal $\mathrm{Hb}$ structure.

Statistical Analysis: Data was analysed using statistical package for social science for windows (release 17.0). Bivariate analysis was done for negative and positive correlation ( $r$ ) between variables. Correlation coefficient (r) between two groups was calculated using Karl Pearson's product method. $\mathrm{P}$ value of $<0.05$ was considered to be significant. The values were represented in number, $\%$ and mean + S.d.

\section{RESULTS}

Patients: Age of the patients ranged from 10 months to 26 (median 4.5) years. Male female ratio was 3.5:1. All the patients belonged to Tharu Chaudhary community. Five patients had fever. Four patients had hepatosplenomegaly. One other patient had splenomegaly alone. One of the patients had jaundice along with fever and weakness.

Results of $\mathrm{Hb}$ electrophoresis revealed presence of $\mathrm{HbF}$ in blood of 8 of 9 patients. $\mathrm{HbF}$ values in patients ranged from $2 \%$ to $96.4 \%$ ( $\mathrm{HbF}$ values of $<2 \%$ were considered as insignificant). High levels of $\mathrm{HbF}(>12 \%)$ were detected in 6 patients. On the basis of results of $\mathrm{Hb}$ electrophoresis, 4 of 9 patients were named as $\beta^{+}$thalassemia major. Hepatosplenomegaly was detected in 2 of 4 patients with $\beta$ thalassemia major, one patient each had $\beta^{+}$and $\beta^{\circ}$ disease. Three other patients had $\beta^{+}$thalassemia minor. One patient each had Sickle cell- $\beta^{\circ}$ thalassemia and $\beta^{+}$thalassemia intermedia (table 1). These 2 patients also had hepatosplenomegaly.

Disease-controls with abnormal Hbstructure: Two subjects with sickle cell disease produced $\mathrm{HbF}$. One of them with heterozygous sickle cell trait had $16.4 \%$ of $\mathrm{HbF}$. Another subject had $0.8 \%$ of $\mathrm{HbF}$ which was considered insignificant.

Disease-controls with normal Hbstructure: One of 8 subjects belonging to this group 


\section{JMSCR Vol||04||Issue||12||Page 14511-14515||December}

produced $\mathrm{HbF}$; this subject was a 9 months old infant and she was still producing $\mathrm{HbF}(8.3 \%)$.

Red cell indices in 3 groups of subjects: Table 2 shows mean values of red cell indices in 3 groups of subjects. As it will appear, the patients had low total $\mathrm{Hb}$ concentration when compared with 2 other groups. Similar low levels were observed in $\mathrm{RBC}$ count and MCV in patients when compared with other disease-control groups.

Relation of $\mathrm{HbF}$ with red cell indices in patients: Results of estimation of $\mathrm{HbF}$ in patients revealed highest $\mathrm{HbF}$ level $(96.4 \%)$ in patient number 9. This patient had total hemoglobin of $8.4 \mathrm{gm} / \mathrm{dl}$, suggesting moderate anemia. Conversely, another patient (no.2) with similar high level of $\mathrm{HbF}(96.1 \%)$ had severe anemia $(\mathrm{Hb}$ $1.7 \mathrm{gm} / \mathrm{dl}$ ). Another patient (no.5) had similar high level of $\mathrm{HbF}(90.8 \%)$ with total $\mathrm{Hb}$ of 6.2 $\mathrm{gm} / \mathrm{dl}$, suggesting severe anemia. Another patient (no.6) had $\mathrm{HbF}$ level of $76.6 \%$ with total hemoglobin of $5.3 \mathrm{gm} / \mathrm{dl}$, suggesting severe anemia. It appeared that the patients with high levels of $\mathrm{HbF}(>70 \%)$ had moderate or severe anemia (table 1).Four patients with relatively high levels of $\mathrm{HbF}$ (nos. 2,5,6 and 9) had mean MCV of $<67$ fl, i.e. $44 \mathrm{fl}, 53 \mathrm{fl}, 48 \mathrm{fl}$ and $66.3 \mathrm{fl}$ respectively, suggesting inverse relationship. Moreover, patient no.1 with moderately elevated $\mathrm{HbF}$ (34\%) had MCV of $43 \mathrm{fl}$, again suggesting an inverse relationship. In contrast to above findings, patient no.3 with $\mathrm{HbF}$ of $20.6 \%$ had MCV of $73.4 \mathrm{fl}$. In patient no.4, similar MCV value of $73.5 \mathrm{fl}$ was detected with relatively low $\mathrm{HbF}$ of $5.1 \%$ (table 1 ).

Table 3 shows that age was related to Hct and $\mathrm{RBC}$ in thalassemic patients $(\mathrm{p}<0.10)$ and with Hct in disease-control subjects with abnormal $\mathrm{Hb}(\mathrm{p}<0.10)$.

Table 4 shows that $\mathrm{HbA}_{2}$ was mildly correlated with Hct and $\mathrm{RBC}$ in patients with thalassemia and with $\mathrm{MCHC}$ and RDW in disease-control subjects with abnormal $\mathrm{Hb}$.

Table 5 shows results of statistical analysis between red cell indices and $\mathrm{HbF}$ in patients. $\mathrm{HbF} \%$ was found to be significantly correlated with $\mathrm{MCHC}$ and also mildly correlated with $\mathrm{MCV}$ $(\mathrm{p}<0.10)$. Total $\mathrm{Hb}(\mathrm{gm} / \mathrm{dl})$ also showed some relationship but it could not come upto the level of mild significance $(\mathrm{p}<0.10)$. Hence, $\mathrm{HbF}$ appeared to have a role in improving $\mathrm{RBC}$ indices.

Table 1 : Shows hematological and $\mathrm{Hb}$ electrophoresis findings in thalassemic patients.

\begin{tabular}{|c|c|c|c|c|c|c|c|c|c|c|c|c|c|c|c|c|}
\hline \multirow{2}{*}{$\begin{array}{l}\text { Patient } \\
\text { no. and } \\
\text { Mean } \\
\pm \text { S.d. }\end{array}$} & \multirow{2}{*}{$\begin{array}{c}\text { Age } \\
\text { in } \\
\text { years }\end{array}$} & \multirow{2}{*}{$\begin{array}{c}\text { Total } \\
\text { Hbgm } \\
\text { /dl }\end{array}$} & \multirow{2}{*}{$\begin{array}{c}\text { Het } \\
\%\end{array}$} & \multirow{2}{*}{$\begin{array}{c}\mathbf{R B C} \\
\text { million/ }^{\mathbf{m}}\end{array}$} & \multirow{2}{*}{$\begin{array}{c}\text { MCV } \\
\text { fl }\end{array}$} & \multirow{2}{*}{$\begin{array}{c}\text { MCH } \\
\text { pg }\end{array}$} & \multirow{2}{*}{$\begin{array}{c}\text { MCHC } \\
\text { gm/dl }\end{array}$} & \multirow{2}{*}{$\begin{array}{c}\text { RDW } \\
\%\end{array}$} & \multirow{2}{*}{$\begin{array}{l}\text { Reticu- } \\
\text { locyte } \\
\text { index }\end{array}$} & \multirow{2}{*}{$\begin{array}{c}\text { Fetal } \\
\text { RBC } \\
\text { (F cells) }\end{array}$} & \multicolumn{5}{|c|}{ Hemoglobin electrophoresis } & \multirow[b]{2}{*}{ Name } \\
\hline & & & & & & & & & & & $\begin{array}{c}\mathrm{HbA} \\
2 \%\end{array}$ & $\begin{array}{c}\mathrm{Hb} \\
\mathrm{S} \\
\%\end{array}$ & $\begin{array}{c}\mathrm{HbF} \\
\%\end{array}$ & $\begin{array}{c}\mathrm{HbA} \\
\%\end{array}$ & $\begin{array}{c}\text { Addit } \\
\text { ional } \\
\text { band } \\
\%\end{array}$ & \\
\hline 1 & 4.5 & 1.8 & 7 & 0.96 & 42.9 & 18.8 & 25.7 & 27.7 & 0.5 & 94 & 1.5 & - & 34 & 64.5 & - & $\begin{array}{l}\beta^{+} \text {Thalassemia } \\
\text { major }\end{array}$ \\
\hline 2 & 13 & 1.7 & 8 & 0.98 & 44 & 19.8 & 26.5 & 27.2 & 0.7 & 94 & 1.1 & 2.8 & 96.1 & - & - & $\begin{array}{l}\text { Sickle cell- } \\
\beta^{\circ} \text { Thalassemia }\end{array}$ \\
\hline 3 & 4.5 & 3.9 & 12.7 & 1.73 & 73.4 & 22.5 & 30.7 & 25.8 & 0.8 & 42 & 1.8 & - & 20.6 & 64.5 & 13.1 & $\begin{array}{l}\beta^{+} \text {Thalassemia } \\
\text { intermedia }\end{array}$ \\
\hline 4 & 16 & 11 & 34.7 & 4.72 & 73.5 & 23.5 & 32 & 13.8 & 0.8 & 0 & 0.8 & - & 5.1 & 94.1 & - & $\begin{array}{l}\beta^{+} \text {Thalassemia } \\
\text { trait minor }\end{array}$ \\
\hline 5 & 2.5 & 6.2 & 29 & 3.21 & 53 & 21 & 28 & 16.1 & 1.3 & 98 & 9.2 & - & 90.8 & - & - & $\begin{array}{l}\beta^{\circ} \text { Thalassemia } \\
\text { major }\end{array}$ \\
\hline 6 & 4 & 5.3 & 13 & 2.82 & 48 & 22 & 29 & 16.8 & 0.4 & 96 & 4.8 & - & 76.6 & 18.6 & - & $\begin{array}{l}\beta^{+} \text {Thalassemia } \\
\text { major }\end{array}$ \\
\hline 7 & $10 / 12$ & 8.6 & 26.1 & 4.02 & 64.6 & 21.4 & 33 & 17.1 & 3 & 54 & 8.4 & - & 2 & 90 & - & $\begin{array}{l}\beta^{+} \text {Thalassemia } \\
\text { minor }\end{array}$ \\
\hline 8 & 26 & 10.2 & 43.5 & 6.6 & 65.7 & 19.9 & 30.8 & 18.5 & 3 & 2 & 12.2 & - & 0 & 87.8 & - & $\begin{array}{l}\beta^{+} \text {Thalassemia } \\
\text { minor }\end{array}$ \\
\hline 9 & 13 & 8.4 & 36.4 & 6.48 & 66.3 & 29 & 28 & 16 & 1.6 & 60 & 3.6 & - & 96.4 & - & - & $\begin{array}{l}\beta^{\circ} \text { Thalassemia } \\
\text { major }\end{array}$ \\
\hline Mean & 9.36 & 6.35 & 23.38 & 3.50 & 59.04 & 21.99 & 29.3 & 19.66 & 1.34 & 60.0 & 4.82 & - & 46.84 & & & \\
\hline S.d. & 8.25 & 3.24 & 13.55 & 2.14 & 12.18 & 2.84 & 2.49 & 5.56 & 1.01 & 39.33 & 4.15 & - & 42.58 & & & \\
\hline
\end{tabular}


Table 2 : Shows mean + S.d. of red cell indices in different groups of subjects.

\begin{tabular}{|c|c|c|c|}
\hline Red cell indices & Thalassemic patients $(\mathrm{n}=9)$ & Disease-controls with abnormal Hb structure $(\mathrm{n}=13)$ & $\begin{array}{c}\text { Disease-controls with normal Hb } \\
\text { structure }(\mathrm{n}=8)\end{array}$ \\
\hline Hbgm/dl & $6.35+3.25$ & $8.8+2.8$ & $8.75+4.35$ \\
\hline $\mathrm{RBC} \mathrm{million} / \mathrm{mm}^{3}$ & $3.5+2.14$ & $4.17+1.7$ & $3.86+1.27$ \\
\hline $\mathrm{MCV} \mathrm{fl}$ & $59.04+12.18$ & $71.9+9.5$ & $68.15+11$ \\
\hline $\mathrm{MCH} \mathrm{pg}$ & $21.99+2.84$ & $23.65+3.7$ & $22.5+5.02$ \\
\hline $\mathrm{MCHC} \mathrm{gm/dl}$ & $29.3+2.49$ & $31.84+3.2$ & $29.23+3.47$ \\
\hline $\mathrm{RDW}$ & $19.66+5.56$ & $16.93+3.01$ & $17.23+3.47$ \\
\hline
\end{tabular}

Significant differences were not obtained, possibly due to small numbers.

Table 3 : Shows relationship of age with red cell findings and hemoglobin electrophoresis values of product moment correlation coefficient ' $r$ '

\begin{tabular}{|c|c|c|c|c|c|c|c|c|c|c|}
\hline Groups & $\begin{array}{c}\mathrm{Hb} \\
\mathrm{gm} / \mathrm{dl}\end{array}$ & $\begin{array}{c}\mathrm{Hct} \\
\%\end{array}$ & $\begin{array}{c}\text { RBC } \\
\text { Million } \\
\mathrm{mm}^{3}\end{array}$ & $\begin{array}{c}\text { MCV } \\
\mathrm{fl}\end{array}$ & $\begin{array}{c}\mathrm{MCH} \\
\mathrm{pg}\end{array}$ & $\begin{array}{c}\text { MCHC } \\
\text { gm/dl }\end{array}$ & RDW & $\begin{array}{c}\text { Reticulo- } \\
\text { cyte } \\
\text { index }\end{array}$ & $\begin{array}{c}\mathrm{HbA}_{2} \\
\%\end{array}$ & $\begin{array}{c}\mathrm{HbF} \\
\%\end{array}$ \\
\hline $\begin{array}{c}\text { Thalassemia patients } \\
(\mathrm{n}=9)\end{array}$ & 0.4698 & $0.5888^{*}$ & $0.5901^{*}$ & 0.2982 & 0.0884 & 0.1056 & -0.1534 & 0.3057 & 0.1757 & -0.2071 \\
\hline $\begin{array}{c}\text { Disease-control with } \\
\text { abormal Hb } \\
(\mathrm{n}=13)\end{array}$ & 0.4507 & $0.5033^{*}$ & 0.2562 & 0.4514 & 0.2422 & 0.2017 & -0.3895 & & 0.3735 & \\
\hline
\end{tabular}

* mildly significant $(\mathrm{p}<0.10)$, other correlations were not found to be statistically significant, most probably due to small sample size $(\mathrm{n}=9)$.

Negative sign (-) shows inverse relationship.

Table 4 shows relationship of hemoglobin $\mathrm{A}_{2} \%$ with red cell findings of product moment correlation coefficient ' $r$ '.

\begin{tabular}{|c|c|c|c|c|c|c|c|}
\hline Groups & $\begin{array}{c}\mathrm{Hb} \\
\mathrm{gm} / \mathrm{dl}\end{array}$ & $\begin{array}{c}\mathrm{Hct} \\
\%\end{array}$ & $\begin{array}{c}\mathrm{RBC} \\
\mathrm{million} \\
\mathrm{mm}^{3}\end{array}$ & $\begin{array}{c}\mathrm{MCV} \\
\mathrm{fl}\end{array}$ & $\begin{array}{c}\mathrm{MCH} \\
\mathrm{pg}\end{array}$ & $\begin{array}{c}\text { MCHC } \\
\mathrm{gm} \%\end{array}$ & $\begin{array}{c}\text { RDW } \\
\%\end{array}$ \\
\hline $\begin{array}{c}\text { Thalassemia Patients } \\
(\mathrm{n}=9)\end{array}$ & 0.4747 & $0.5897^{*}$ & $0.5349^{*}$ & 0.1037 & -0.1931 & 0.3327 & -0.476 \\
\hline $\begin{array}{c}\text { Disease- control with abnormal Hb } \\
(\mathrm{n}=13)\end{array}$ & $0.2522^{*}$ & -0.3204 & 0.2096 & -0.0129 & -0.0018 & $0.5331^{*}$ & $-0.5793^{*}$ \\
\hline
\end{tabular}

* mildly significant $(\mathrm{p}<0.10)$. Negative sign (-) shows inverse relationship.

Table 5 : Correlation between HbFVs different red cell indices in patients with thalassemia.

\begin{tabular}{|c|c|c|}
\hline HbFVs Red cell indices & Correlation coefficient ' $r$ ' & $\mathrm{p}$ value \\
\hline HbFVsHb & -0.4404 & $>0.10$ \\
\hline HbFVsHct & -0.2645 & $>0.10$ \\
\hline HbFVs RBC & -0.2053 & $>0.10$ \\
\hline HbFVs MCV & $-0.5564^{*}$ & $<0.10$ \\
\hline HbFVs MCH & 0.2784 & $>0.10$ \\
\hline HbFVs MCHC & $-0.7177^{* *}$ & $<0.05$ \\
\hline HbFVs RDW & 0.0066 & $>0.50$ \\
\hline HbFVs reticulocyte index & -4449 & $>0.10$ \\
\hline$* *$ statistically significant at 5\% level of significance $(\mathrm{p}<0.05)$. Negative sign (-) shows inverse relationship.
\end{tabular}

\section{DISCUSSION}

Present study showed an inverse relationship between $\mathrm{HbF}$ levels and total $\mathrm{Hb}$ concentrations in 5 of 6 high $\mathrm{HbF}$ producing $\beta$ thalassemic patients. Similar negative correlation was found between HbFVsHct, RBC, MCHC and MCV. Clearly, our findings suggested that patients with moderate and severe anemia had increased levels of $\mathrm{HbF}$. However, in another study involving patients with thalassemia interna, median $\mathrm{HbF}$ level was $37.2 \%$ and $\mathrm{HbF}$ levels correlated positively with total hemoglobin ${ }^{4}$.
In 2 patients, mild rise in $\mathrm{HbA}_{2}$ was seen $(9.2 \%$ and $12.2 \%$ ). Mild rise in $\mathrm{HbA}_{2}$ might have partially improved hypochromia. In our $\beta$ thalassemic patients, $\mathrm{MCH}$ ranged from $18.8 \mathrm{pg}$ to $29 \mathrm{pg}$, showing direct correlation between $\mathrm{HbFVs} \mathrm{MCH}$. In this study, $\mathrm{HbF}$ showed positive correlation with RDW in thalassemic patients. In another study, RDW values were higher in patients than in normal controls ${ }^{1}$.

These observations supported the contention that $\mathrm{HbF}$ might improve the survival of red cells in thalassemia. These findings were consistent with 
the results of other studies ${ }^{5-8}$. In addition, growth of Plasmodium falciparum is retarded in red cells with fetal hemoglobin resulting in selective advantage for $\beta$ thalassemia heterozygates in whom postnatal $\mathrm{HbF}$ declines at a lower than normal rate ${ }^{9}$ Furthermore, persons with thalassemia are more susceptible to yersinia enterocolitica infection ${ }^{10}$.

Another important clinical feature of this study was the detection of hepatosplenomegaly in 4 patients. Higher affinity of $\mathrm{HbF}$ may lead to increased release of erythropoietin, resulting in development of extra medullary foci of erythropoiesis in liver and spleen. Moreover, accelerated erythropoiesis may also enhance iron absorption $^{11}$.

\section{CONCLUSION}

Fetal hemoglobin production in $\beta$ thalassemia may correct hypochromia and may promote survival of red cells. Detection of hepatosplenomegaly in thalassemia syndrome may be due to extra medullary erythropoiesis. Increased erythropoiesis may enhance iron absorption and augment pathology.

\section{Financial support and sponsorship: Nil}

Conflicts of interest: There are no conflicts of interest.

Ethics approval: Present study was approved by the ethical committee of Nepalgunj Medical College, Nepal. Written consent was taken from all the subjects included in this study.

\section{REFERENCES}

1. Lafferty JD, Crother MA, Ali MA, Levine ML. The evaluation of various mathematical RBC indices and their efficacy in discriminating between thalassemic and non-thalassemic microcytosis. Amer J clinpathol 1996, 106:201-5.

2. Lewis SM, Bain BJ and Bates I. Dacie and Lewis Practical Haematology, $9^{\text {th }} \mathrm{ed}$, London : Churchill Livingstone; 2001, p 275-276.
3. Fischback Talaska Frances. Dunning III Marshall Barnett: A manual of laboratory and diagnostic tests $8^{\text {th }}$ ed. New Delhi :Wolters Kluwer/Lippincott Williams and Wilkins; 2009, p108-110.

4. Musallam KM, Sankaran VG, Cappellini MD, Duca L, Nathan DG, Taher AT. Fetal hemoglobin levels and morbidity in untransfused patients with $\beta$ thalassemia intermedia. Blood 2012; 119(2) : 364-367.

5. Telen MJ, Kaufman RE. Wintrobe's Clinical Hematology $10^{\text {th }}$ ed. Baltimore. Maryland: Williams and Wilkins; 1999, p1342-1343.

6. Wheatherall DJ, editor. The molecular basis of blood disease. $2^{\text {nd }}$ ed. Philadelphia: WB Saunders Company; 1994, p157.

7. AsadovChD, Mamedova TA, Kulieva ED, Shakhguseinova SB. Diagnosis of $\beta$ thalassemia. Klin Lab Dign; 2004, 5:45-7.

8. Ahmed S, Saleem M, Modell B, Pertrou M. Screening extended families for genetic hemoglobin disorders in Pakistan. N Eng J Med 2003; 347: 1162-68.

9. McKerrow JH, Davies SJ. Parasitic diseases. In :Parslow $\mathrm{TG}$ et al editors Medical Immunology, $4^{\text {th }}$ ed. New York : Elsevier; 1997, p673-75.

10. Hamilton SR, Farber JL, Rubin E : The gastrointestinal tract. In 'Pathology' $3^{\text {rd }}$ edition, Rubin E, Farber JL (editors), Lippincott-Raven (publishers), Philadelphia, p705, 1998.

11. Bonner H, Bogg A, CossmanJ : The blood and lymphoid organs. In 'Pathology' $3^{\text {rd }}$ edition, Rubin E, Farber JL (editors), Lippincott-Raven (publishers), Philadelphia, p1078. 